\title{
WE WILL FEED OUR AND A NEW WORLD: SEVERAL CASES OF FOOD WAYS OF FRONTIER REGIONS. PART 2
}

\section{Serguey N. Yakushenkov}

Astrakhan State University. Astrakhan, Russia. Email: shuilong[at]mail.ru

\begin{abstract}
This article is the second part of the study of regional foodways. If the first part is devoted to the analysis of the foodscape of Astrakhan, the second part analyzes the food system of the Republic of Peru. The choice of this object of study is based on the frontier nature of the region, the diversity of economic and cultural types, and hybridity. All these factors allow us to compare the ways of formation of the foodways of these regions.
\end{abstract}

The Peruvian alimentary landscape began to form in the 16th century, after the conquest of Peru by the Spanish conquistadors. As a result of mutual influences and struggles between elements of autochthonous and alien cultures, a new "hybrid" phenomenon takes shape. The turning point in the development of national cuisine was in the 1930s, when, as a result of gastropolitical strategies, the government managed to create a food system accessible to the workers of large cities. The opening of "people's restaurants" allowed workers to have calorie-dense food. It also contributed to the creation of a national food system.

The search for national identity among the Peruvian elite led to the "discovery" of their national roots. The fact that Peruvian culture was based on natural and ethnic diversity made the country's alimentary system diverse and rich. This process coincided with global trends in the approach to food in the sense of a focus on "simple" and "healthy" peasant foods, as opposed to foods undergone of maximum processing. Ultimately, this was manifested in the creation of a "new Andean cuisine" that embraced Peru's centuries-old traditions and the country's natural diversity. In doing so, Peruvian restaurateurs used both familiar approaches to business and invented new ones that went beyond the culinary arts. As a result of the efforts of many culinary masters and restaurateurs, in competition with internationally renowned culinary brands, a new global culinary brand has been created, recognized around the world.

\section{Keywords}

foodscapes; frontier; hybridity; Republic of Peru; cultural development; regionalism; globalism

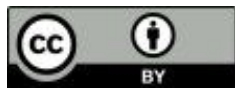

This work is licensed under a Creative Commons «Attribution» 4.0 International License 


\section{МЫ НАШ И НОВЫЙ МИР НАКОРМИМ: НЕСКОЛЬКО КЕЙСОВ АЛИМЕНТАРНЫХ ТРАДИЦИЙ ФРОНТИРНЫХ РЕГИОНОВ. ЧАСТЬ 2}

\section{Якушенков Сергей Николаевич}

Астраханский государственный университет. Астрахань, Россия. Email: shuilong[at]mail.ru

\section{Аннотация}

Данная статья представляет собой вторую часть исследования региональных алиментарных систем. Если первая часть посвящена анализу алиментарного ландшафта Астрахани, то во второй части проводится анализ алиментарной системы Республики Перу. В основу выбора этого объекта исследования положены фронтирность региона, разнообразие хозяйственных и культурных типов, гибридность. Все эти факторы позволяют сопоставлять пути формирования алиментарных систем этих регионов.

Перуанский алиментарный ландшафт начинает формироваться в XVI в. - с момента завоевания Перу испанскими конкистадорами. В результате взаимовлияния и борьбы элементов автохтонной и пришлой культур и происходит формирование нового «гибридного» явления. Переломным моментом в развитии национальной кухни являются 30-е гг. XX в., когда в результате гастрополитических стратегий правительству удалось создать доступную для рабочих крупных городов систему питания. Открытие «народных ресторанов» позволило трудящимся получать калорийную пищу. Это также способствовало созданию национальной системы питания.

Поиск национальной идентичности в среде перуанской элиты привели к «открытию» своих национальных корней. Тот факт, что перуанская культура зиждилась на природном и этническом своеобразии, делал алиментарную систему в этой стране разнообразной и богатой. Этот процесс совпал с мировыми тенденциями в подходе к пище, выразившиеся во внимательном отношении к «простой» и «здоровой» крестьянской пище, противопоставляемой пище, подвергаемой максимальной переработке. В конечном итоге это нашло отражение в создании «новой андской кухни», в которой реализовались многовековые традиции Перу и природное разнообразие страны. При этом перуанские рестораторы использовали как уже известные подходы к бизнесу, так и изобретали новые, выходящие за рамки кулинарного искусства. В результате усилий многих кулинарных мастеров и рестораторов удалось в конкурентной борьбе со всемирно известными кулинарными брендами создать новый мировой кулинарный бренд, признанный во всем мире.

\section{Ключевые слова}

алиментарный ландшафт; фронтир; гибридность; Астраханская область; Республика Перу; культурные процессы; регионализм

Это произведение доступно по лицензии Creative Commons «Attribution» («Атрибуция») 4.0 Всемирная 


\section{ВСТУПЛЕНИЕ}

В предыдущей части нашего исследования мы анализировали алиментарный ландшафт Астраханской области (Якушенков \& Палаткин). Выбор объекта исследования был детерминирован рядом факторов, которые мы посчитали особо важными для нашего исследования. Среди этих факторов, основными на наш взгляд, были наличие разнообразных экологических зон, которые предопределили и наличие в регионе разных типов хозяйственной культуры: рыболовство, скотоводство, земледелие и охота. Другим важным фактором, оказавшим важное влияние на формирование алиментарного ландшафта в регионе, была поликультурная среда, т.е. наличие множества этнических групп, как «автохтонных», так и прибывших относительно в позднее время.

Важнейшим импульсом для нашего исследования был также тот факт, что оба региона представляют собой фронтирные регионы, в которых эта фронтирная составляющая определяла доминанту их развития. Во многом эта фронтирность сохраняется и по сей день, однако теперь она выражена в иной форме, и не всегда доминирует в экономических и культурных региональных процессах.

Эти факторы послужили для нас отправной точкой для компаративистских исследований, направленных на сопоставление генезиса алиментарного ландшафта в крае, с типологически и топологически сходными явлениями. В качестве подобного объекта для сравнения мы выбрали Центральные Анды, и в частности Республику Перу, так как посчитали, что данный кейс позволяет нам сравнивать как схожие модели развития, так и сопоставлять совершенно разные пути развития алиментарного ландшафта в конце XX - нач. XXI вв..

Мы уже говорили в первой части, что мы осознаем таксономически разные единицы нашего анализа. В одном случае это лишь территория в составе национального государства (Астраханское царство, Астраханская губерния, Астраханская область), а с другой национальное государство (Республика Перу). Однако, не следует забывать, что длительное время данная территория - Вице-королевство Перу - также являлось частью огромной империи, и получила независимость относительно недавно. Длительное время развитие культурного ландшафта Перу проходил в рамках колониальной истории. А во второй половине $\mathrm{XX}$ в. здесь доминировали глобалистские тенденции.

На наш взгляд, для исследователя особенно важны те конструктивные изменения, которые произошли в алиментарном ландшафоте 
Перу за последние десятилетие XX в. и первые два десятилетия XXI в.. Пример с Перу продемонстрировал то, как алиментарный ландшафт (мы здесь не говорим про всю культуру в целом) может не только выстоять в борьбе с глобалистскими тенденциями, но и добиться признания как в рамках национального пространства, но и в культурных пространствах ведущих стран мира (Великобритания, США и т.д.). Именно эти моменты заслуживают внимательного изучения, тем более отправная точка этих изменений совпадала по времени с серьезными социальными и экономическими трансформациями, происходящими в нашей стране.

Изучение перуанской модели демонстрирует удивительные моменты совпадений в развитии с российской ситуацией в целом, и астраханской в частности. Порой эти совпадения случайны, но во многом продиктованы схожими условиями развития.

Вместе с тем, примечательно то, как население осознает свою уникальность, аутентичность, и стремится эту аутентичность познать. Мы уже говорили, что перуанские ученые проявили огромный интерес к своему алиментарному ландшафту, посвятив ему огромное количество самых разнообразных исследований. При этом изучаются как исторические аспекты перуанской кухни, так и ее современное состояние (Olivas Weston, 1996; 1998; 1999; 2008; 2015; Villavicencio, 2007; 2017; Guardia; León; Cartay; Clausen de Molina; Lauer; Orefici.). Мы привели здесь лишь небольшой список книг, посвященных перуанской кухне ${ }^{1}$.

Это наводит на мысль, что перуанские ученые в большей мере осознают всю важность вопроса изучения и пропаганды культурного наследия своих народов (Benavides de Rivero; Benites).

\section{ОСНОВНАЯ ЧАСТЬ. ПЕРУАНСКАЯ МОДЕЛЬ: ОТ ФРОНТИРНОЙ ГАСТРОНОМИИ К ГЛОБАЛЬНОМУ ТРЕНДУ}

Данная модель начала складываться на основе нескольких этнокультурных компонентов. В основе ее лежат алиментарные традиции Центральных Анд в их нескольких вариантах. В первой половине XVI в. к ним добавилась испанская модель, так как в 1530-33 гг.

1 Мы осознаем некоторую некорректность сравнения числа выпушенных книг по перуанской кухне и астраханской. Ведь если бы нам пришлось сравнивать, например, с российской печатной продукцией, то ситуация была бы приблизительно схожей. Однако, и численность населения этой страны почти в пять раз меньше, чем в России, мы здесь умолчим про территорию, да и природное разнообразие нашей страны. Кроме этого, мы вынуждены признать наличие в Перу мощных научных центров по изучению национального алиментарного ландшафбта и отсутствие подобных центров в нашей стране. 
империя инков Тауантинсуйо была покорена испанскими конкистадорами, а местное население было превращено в подневольных крестьян, обязанных работать на колонизаторов (Cieza de Leon; Prescott). Столица инков Куско оказалась разрушенной, а испанцы в 1535 г. основали город Лиму, который позднее стала новой столицей вице-королевства Перу.

Как уже говорилось в предыдущей части, отличительной чертой обеих регионов было их природное разнообразие. Именно этот фактор сыграл решающую роль, как нам кажется, в формировании хозяйственных и пищевых моделей населения Центральных Анд..

В силу географического своеобразия региона здесь сформировалась особая хозяйственная модель, названная вертикальной экологией или вертикальным архипелагом (Murra, 1975). В упрощенном виде эту хозяйственную модель можно представить в виде определенных вертикальных зон, население которых активно взаимодействовало друг с другом: Коста, Сьерра и Сельва или западное побережье, высокогорная зона и зоны восточные леса. В ином варианте эту схему можно изобразить следующим образом: Коста - это рыболовство и земледелие, Сьерра - высокогорное земледелие и скотоводство (камелиды), Сельва - тропическое земледелие и охота. Все три зоны имели тесные экономические и культурные связи друг с другом. И хотя политическую основу андских государств, как правило, составляли политии, расположенные в Сьерре, однако, все они на протяжении длительного времени владели дополнительными колониями в Косте и Сельве. Ну а государство Тауантинсуйо располагалось сразу в трех зонах, так что контроль природных ресурсов на этой территории осуществлялся в полной мере, хотя, конечно, в значительной степени рацион основной массы населения этого государства составляли овощи и злаки, с небольшим дополнением мяса домашних животных (камелиды и морские свинки). Специфика вертикального архипелага заключалась в том, что высокогорные сообщества старались создать на западном побережье и на восточных склонах Анд дополнительные колонии, где жители производили местную сельхозпродукцию для снабжения высокогорных селений дополнительными пищевыми ресурсами (Goldstein, pp. 188-190; Якушенков, 1988).

Не стоит забывать, что высокогорные районы Перу можно считать родиной картофеля (Solanum tuberosum), возраст доместикации которого насчитывает около 10000 лет (Engel), так что мир обязан этому региону этим ценным продуктом. Высокогорье подарило миру и еще такой злак, ставший очень модным в настоящий момент, как киноа (Chenopodium quinoa), относящийся к семейству амарантовых. ООН 
объявило 2013 г. «Годом киноа», назвав его злаком будущего (A Future Sown Thousands of Year Ago, 2013). Кроме этих двух важнейших культур следует упомянуть такие культурные растения, как клубненосные ока (Oxalis tuberosa), уллюко (Ullucus tuberosus), настурцию или исанью (Tropaeolum tuberosum), а также злак каньауи (Chenopodium Sp.), родственный отечественной мари, ну и, конечно, кукурузу, играющую огромную роль в рационе перуанцев ${ }^{1}$.

К этим растениям нужно добавить огромное колличество самых разнообразных тропических фруктов: разные виды анон (чиримоя, гуанабана), плоды пальмы агухе (Mauritia flexuosa), плоды перуанского физалиса (Physalis peruviana), каму-каму (Myrciaria dubia), капулин (Prunus salicifolia), называемое также «горной черешней», кокона (Solanum sessiliflorum), гуава (Psidium guajava), плоды пасифлор гранадилья (Passiflora ligularis), тумбо (Passiflora supersect. Tacsonia) и маракуя (Passiflora edulis), лукума (Pouteria lucuma), манго, авокадо и многие многие другие.

Легко убедиться, что многие фрукты стали частью мировой кулинарной культуры, и активно выращиваются и потребляются в пищу во многих странах мира. В том числе и на Нижней Волге. В некоторых частных садах региона можно встретить тот же физалис, а манго, авокадо, гранадилью, маракуя, некоторые вида анон можно приобрести и в местных магазинах во многих уголках России. Но и более экзотические фрукты из перуанских тропиков стали доступны в различных уголках мира. Так около 10 лет назад в Японии стал популярен фрукт каму-каму, доставляемый из Перу (Peruvian Camu Camu fruit conquers Japan).

Завоевание Центральных Анд испанцами в некоторой степени изменило алиментарный ландшафт региона. Значительная часть региона была идеальной для занятий скотоводством: разведением крупного рогатого скота, овец, свиней. Все это разнообразило мясной рацион отдельных слоев населения Перу. Вместе с тем, данные нововведения не могли серьезным образом повлиять на систему питания индейцев, так как значительная часть коренного населения Перу продолжает жить в зоне высокогорья (выше 3 тыс. метров над уровнем моря), где возможности для разведения коров, овец или свиней в значительной мере ограничены. Разведение камелидов (лам и альпак) было и остается единственным возможным направлением животноводства.

1 Кукуруза имела и продолжает сохранять особое значение в культуре перуанцев. Недаром индейцы кечуа называли ее 'Сара Мама' - «мать-кукуруза», считая ее священным растением (Steward, 1946, p. 216) 
Этот краткий очерк алиментарного ландшафта Центральных Анд был бы неполный, если бы мы не упомянули о такой важной хозяйственной сфере народов этого региона, как рыболовство и сбор морепродуктов. Учитывая тот факт, что Перу располагается вдоль Тихого океана и линия морского побережья имеет протяженность более 3000 км, легко предположить, что морское рыболовство получило в этой стране большое распространение. Рыба и морепродукты являются важнейшей частью рациона населения этой страны, особенно городского. Еще в древности на территории Косты, т.е. побережья, возникли цивилизации, население которых активно занималось морским промыслом: Паракас, Mоче (Benson) и т.д.. В конце XX нач. XXI вв. Перу занимало ведущее место в мире по объему выловленной рыбы (в основном анчоусов и сардин) (National Fisheries Sector Overview Peru, 2020).

Помимо морской рыбной ловли и сбора молюсков, на части территории Перу находится самое высокогорное в мире озеро Титикака, где также развито рыболовство, а местная этническая группа индейцев уру сформировалась на основе рыболовства, так как эти индейцы были оттеснены другими этническими группами в центр озера и жили на искуственных островах из тростника (Stanish, pp. 52-57).

Длительное время перуанский культурный ландшафот развивался в значительной степени под влиянием двух основных культурных традиций: испанской культуры и традиционных индейских. Французский морской офицер Максмильян Радиге (Maximiliano Radiguet), посетивший Лиму в 1841 г., отмечал, что сопротивление индейским традициям шло по линии использования кастрюль и сковородок: «классическая кастрюля и сковорода испанской кухни до сих пор являются способами сопротивления в высших кругах» (Radiguet, p. 105).

Конечно, не только испанская посуда стала неотъемлемой частью новой перуанской кухни. Сюда следует добавить молочные и хлебные продукты, свинину, говядину, новые специи, вино, крепкий алкоголь и многое другое. Однако, не следует воспринимать столичную кухню, с которой познакомился М. Радиге, как некую типичную (рp. 104-106). Она скорее была исключением, чем классическим примером, так как основная масса населения продолжала жить высоко в горах и придерживалась многовековых традиций доиспанского периода.

В Лиме и других крупных городах на базе испанской и традиционной индейской кухни к XIX в. сформировалась креольская кухня, представлявшая собой некий фьюжин. 
Примечательно, что М. Радиге отмечал влияние французской моды на перуанских женщин. Он даже считал, что здесь ее влияние гораздо сильнее чем в какой-нибудь французской провинции (р. 103), однако, он нигде не обнаружил влияние французской кухни.

Вместе с тем, об окончательном формировании креольской кухни можно говорить лишь к началу XX в., когда к уже имеющимся традициям индейско-испанской кухни добавились итальянская, китайская и японская.

При этом все три кухни вступили в активное соперничество за вкусы перуанцев, формируя все новые и новые кулинарные подходы в стиле фьюжин. И, конечно, этот список был бы неполным, если бы мы не упомянули африканских рабов, привнесших в этот алиментарный ландшафт свой колорит и свое видение вкусной пищи. Правда, первоначально влияние африканской культуры было ограничено территориально (некоторые районы Косты, куда африканских рабов завозили для работы на сахарных плантациях) и социально, так как эта группа населения была максимально сегрегирована (Ndi, 2018). Вместе с тем, роль африканских кулинарных традиций в перуанской кухне весьма значительна, особенно это характерно для кулинарных традиций Косты.

Как считал американский историк Арнольд Бауер, перуанский алиментарный ландшафт длительное время оставался фрагментарным, так как расовая и этническая разобщенность давала себя знать. Эта ситуация, по его мнению, сохранялась до 40-х и даже 50-х гг. XX в. (Bauer, 2001, p. 194).

Таким образом, перуанская кухня - это совокупность самых разнообразных практик: индейской, среднеземноморской (испанской и итальянской) и африканской, со значительным добавлением восточной (китайской и японской).

Но не следует понимать этот процесс «сплавления» этих традиций как нечто однолинейное и механическое. Формирование перуанского алиментарного ландшафоқа - это процесс очень долгий и достаточно противоречивый. Во многом этот ландшафт - результат особой гастро-политики, как это назвал американский антрополог А. Аппадурай, понимая под этим термином особую политику выстраивания алиментарных норм: регламентацию доступа населения к определенным ресурсам, управление процессом потребления и т.д. (Appadurai, pp. 494-496).

В начале 30-х гг. XX в. государственная политика в этой сфере приняла весьма драматичные формы, направленные на создание определенной стратегии функционирования национальной системы 
питания для рабочего класса. Сложная ситуация экономической депрессии, в которой оказались многие страны мира, больно ударила и по Перу, превратившемуся в сырьевой придаток развитых капиталистических стран. Все это привело к еще большему обнищанию рабочего класса и усилению политической борьбы. В этих условиях правительство Луиса Мигеля Санчеса Серро (1930-1933) начало претворять в жизнь программу по созданию национальной системы дешевого и здорового питания. Она состояла из открытия «народных ресторанов» - restaurantes populares, как особого механизма улучшения питания рабочего класса и борьбы с азиатскими заведениями общественного питания, которые воспринимались общественностью как негигиеничные и содержащие низкокалорийную пищу (Drinot).

Кроме этого, restaurantes populares выполняли, по мнению Пауло Дринота, еще очень важную функцию - они помогали формированию рабочей идентичности и перуанского национализма (pp. 246-247).

Слова Бауера по поводу«фрагментарности» перуанской кухни можно отнести и ко всей перуанской культуре, да и этно-социальной системе перуанского общества. Внутри ее было очень много противоречий, завязанных именно на этно-социальную структуру Перу и особенно Лимы. Мы не будем подробно останавливаться на этом вопросе, так как, на наш взгляд, П. Дринот очень хорошо показал все это. Он также достаточно подробно проанализировал совместно с Карлосом Контреросом все процессы, происходившие в Перу в период Великой депрессии (Drinot \& Contreras).

Как нам кажется, именно restaurantes populares послужили той отправной точкой формирования национальной кухни, ставшей в последствии признанным феноменом национального культурного наследия Перу.

Конечно, эти события 30-х гг. явились лишь одной из начальных фаз складывания этого общенационального ландшафта. Но они весьма закономерно совпали с общенациональными тенденциями формирования национальной культуры. Неудивительно, что следующий этап формирования нового культурного ландшафта Перу вновь совпал с важным периодом в жизни страны. Эти новые изменения в жизни страны были вызваны приходом к власти левацки настроенных военных под руководство генерала Х. Веласко Альварадо, возглавившего страну в 1968 - 1975 гг.. Проведение структурных социальных и экономических реформ, изменило перуанское общество, вызвав к жизни активность народных масс, главным образом индейцев Сьерры (кечуа и аймара). Предыдущие эпохи социального и этниче- 
ского разобщения были в значительной мере преодолены новыми реформами правительства левых генералов. Правда, это привнесло новые проблемы в жизнь Перу, но индейцы неожиданно почувствовали свою значимость и важность для страны. С приходом Веласко Альварадо непреодолимая пропасть между миром индейцев гор и белых жителей крупных городов (Лимы, Арекипы, Куско, Аякучо и др.) была уничтожена. Повсюду формировались новые мостики, соединявшие эти два мира. Но к ним добавлялись и новые миры: афроамериканцы Косты и метисное население Сельвы, которое также получило новые экономические и социальные возможности для активного участия в жизни страны.

Именно на волне всех этих процессов и родилось такое явление, как «новая андская кухня» (cocina novoandina). Сложно сказать, когда действительно началось это движение, но за основу берут 1986 г., когда известный повар и издатель, общественный деятель Бернардо Рока Рей Миро Кесада «изобрел» блюдо, получившее название «Горшочек из Уакачины» (Olla de Huacachina). Хотя блюдо получилось совершенно случайно, так как оно создавалось как некий вызов международной команде поваров на кулинарном фестивале, организованном Гастрономической Ассоциацией Перу (Gastronomical Association of Peru AGAPE), на котором Бернардо Рока Рей был судьей, да и одним из организаторов этого фестиваля. Чтобы приготовить это блюдо, он просто пошел на местный рынок в соседний городок Ику и купил там различные местные продукты.

Концепт новой андской кухни заключался в неповторимом сочетании двух тенденций: мировой и местной. Здоровая крестьянская еда очень хорошо вписывалась в общемировую тенденцию повышения значимости здоровой пищи. Поменялись и другие тенденции, доминировавшие на протяжении нескольких веков в кулинарном ландшафте белого населения Перу. Эти тенденции группировались вокруг таких бинарных оппозиций как домашняя кухня :: ресторанная; простая кретьянская еда :: изысканная европейская и т.д.. Обеды вне дома до этого казались достоянием только аристократов, имеющих возможность питаться вне дома. Но как мы видим, с введением в традицию restaurantes populares, даже рабочие получили возможность питаться вне дома, и платить за это умеренную цену. Вместе с тем и в 90-е гг XX в. влияние изысканной французской кухни в перуанской столице и других крупных города Перу было очень велико. Она еще долго оставалась неким эталоном качества. То, что Бернардо Рока Рей Миро Кесада неожиданно обратился к местной кухне и местным алиментарным традициям было самым настоящим вызовом, так как 


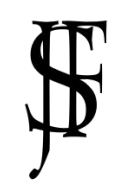

Журнал Фронтирных Исследований. 2021. No 3 | ISSN: 2500-0225

Фронтир в мировом контексте | Doi: https://doi.org/10.46539/jfs.v6i3.321

он представлял очень богатый и влиятельный в Перу клан, насчитывающий не один десяток различных очень влиятельных и богатых людей этой стран - политиков, адвокатов, ученых, врачей, финансистов, и т.д.. Можно без всякого сомнения назвать его одним из ярчайших представителей перуанской элиты. Возможно, именно этот факт был, если не решающим, то достаточно важным в оформлении этого явления - новая андская кухня.

Вне всякого сомнения можно с огромной уверенностью утверждать, что именно перуанская элита проявила этот исключительный интерес к своим национальным корням. И пусть индейские или африканские корни были лишь некоторой метафорой, но причастность к этой национальной культуре ощущалась ими очень сильно. Это очень заметно и по другой национальной тенденции - музыкальной культуре. Народные массы не давали элите забывать о себе и своей политической активностью, нередко крайне левацкого (маоистскотроцкистского толка) движения Сендеро Луминосо («Светлый путь»), и своей теперь более значимой ролью в жизни страны.

Теперь элита оказалась также дефрагментированной - разорванной между старыми классическими образцами европейской культур и новыми тенденциями национальной культуры. Другой видный представитель движения cocina novoandina Гастон Акурио заявлял в интервью журналистке Лауре Фрейзер, что, когда он из Парижа ехал в Перу, он «хотел приучать перуанцев есть фуагра и трюфели» (Fraser, p. 100). Но работа в Перу кардинальным образом поменяла его видение современной кухни. И он вместе со своей женой француженкой немецкого происхождения Astrid открывает ресторан, меню которого постепенно начинает ориентироваться на традиционную перуанскую кухню.

Пример Г. Акурио заслуживает особого внимания, так как он, также как Бернардо Рока Рей, происходил из высших слоев перуанской элиты. Его отец - видный политик, правая рука бывшего президента Белаунде Терри (1963 - 1968; 1980 - 1985) мечтал, чтобы его сын получил профессию юриста и стал, как и он, политиком. После окончания юридического факультета перуанского университета он послал его для продолжения учебы на адвоката в Мадрид. Каково было разочарование отца, когда спустя какое-то время сын заявил ему, что не хочет быть юристом, а хочет быть поваром.

Для перуанской элиты даже в начале 90-х гг. XX в. повар был всего лишь обслуга. Уважаемый человек из известной семьи не может быть поваром. Такие люди не должны заниматься поварским искусством. Но сын настоял на своем. 
Когда Гастон Акурио вернулся в Перу, там уже было несколько ресторанов, сфокусировавших свое меню на новоандской кухне. Это пржде всего Луис Кучо Ла Роса с его рестораном «El Comensal» и дочь Бернардо Рока Рея Ирка Рока Рей с ее рестораном «Pantagruel».

Возможно, лишь Луис Кучо был выходцем из простого народа. Он начал работать 1973 г., когда ему было 15 лет в качестве простого бармена в маленькой закусочной в Лиме, которую открыл его отец, много путешествовал, знакомясь с гастрономическими традициями Перу. Поэтому, когда в 1994 г. он открыл свой ресторан с новоандской кухней, он уже достаточно хорошо знал, что нравится простым перуанцам и какие уникальные продукты имеются в стране.

И хотя оба первоначальных проекта («El Comensal» и «Pantagruel») со временем перестали существовать, они вместе с ресторанами Г. Акурио заложили основу для новой гастрономической культуры.

Вместе с тем, вряд ли этот процесс был бы успешным вне контекста процесса глобализации. Как ни странно, именно он, на наш взгляд, дал дополнительный толчок к развитию новой национальной кухни в Перу. Уже изначально собственно перуанский процесс алиментарной самоидентификации совпал с международным глобалистским процессом, выразившимся в огромном интересе западного человека к кухне народов мира. Конечно, много сделано было такими людьми как Бернардо Рока, который будучи членом совета директоров и одним из совладельцев такого печатного новостного издания как El Comercio, постоянно пропагандировал перуанскую кухню в виде статей, и дешевых кулинарных книг, которые время от времени подписчики газеты El Comercio получали вместе с газетой.

Но национальная кухня - это не только то, о чем мы говорим и то, что мы считаем таковой. Это прежде всего то, что мы едим, как ежедневно, так и по особым праздничным дням. Поэтому происходившее в 90-е и 2000-е гг. в Перу заслуживает особого внимания. И не только в силу уникальности этой кухни, но и в силу особых культурных процессов, выведших ее в ряд мировых брендов.

На сегодняшний день тот же Гастон Акурио открыл более двух десятков ресторанов по всему миру: Латинская Америка, США, Европа, Катар. Он начал завоевание международных рынков с Сантьяго в Чили (1999), Колумбии (2003), Мексике (2007) и т.д. (Tristán \& Serida-Nishimura, p. 85).

Исключительность этого явления заключается еще и в том, что перуанские повара постоянно предлагают уникальное сочетание вкусов и стилей: перуано-итальянская кухня; перуано-японская (nikkei); 
перуано-китайская (chifa), перуанская креольская, аф̆ро-перуанская, морская, и т.д..

Некоторые блюда перуанской кухни уже действительно снискали всемирное признание. Среди подобных блюд можно назвать, например, севиче, представляющее собой маринованную рыбу в соке лайма со специями. Существует несколько десятков разных региональных способов приготовления этого блюда, и в каждом из них будет неповторимое сочетание ингредиентов. В начале второго десятилетия XXI в. в одной Лиме насчитывалось 11000 севичерий - то есть кухонь, специализировавшихся на приготовлении севиче (Kraig \& Sen, р. 13). При этом это как специальные заведения с моноблюдом (севиче), так и крупные рестораны высокой кухни, который включали в свое меню это блюдо. Многие туристы со всего мира специально приезжают в Лиму, чтобы попробовать местные севиче. Можно с уверенностью сказать, что в настоящий момент гастрономический туризм в Перу столь же развит, как и посещение различных достопримечательностей - прежде всего археологических мест, типа Мачу-Пикчу, крепости Саксайуаман, долины Наска и т.д..

Нобелевский лауреат в области литературы перуанец Марио Варгас Льоса в своей речи, посвященной Гастону Акурио отмечал, что сейчас многие перуанские юноши мечтают стать поварами, как когда-то мечтали стать психологами, а еще раньше экономистами, а до этого архитекторами (Llosa, 2009). Средняя зарплата повара в элитном ресторан в Лиме около 5000 US\$ (Tristán \& Serida-Nishimura, p. 93). И хотя у начинающего повара с профильным образованием будет всего лишь 350 US\$, это также можно считать неплохим заработком в Перу, с учетом того, что данный субъект всега легко найдет работу, так как в Перу каждый день открывается более полутора десятков новых ресторанов (Tristán \& Serida-Nishimura, p. 93). А гастрономический туризм дает рабочие места все новым и новым перуанцам, так как он завязан на самые различные сферы деятельности, и прежде всего на производство сельскохозяйственной продукции, рыболовство, технологические отрасли, выстраивание новых логистических модулей и т.д..

Гастрономический туризм постоянно создает новые формы и новые институты, так как кулинарный бизнес - это не только сфера приготовления и потребления. Избалованный, особенно международный турист, хочет за свои деньги особых условий потребления. И претензии предъявляются не только к качеству приготовленной еды, но и к обслуживанию, и общей атмосфере заведения, и т.д.. Все это требует особого персонала этих заведений, высококлассных 
дизайнеров, техников по обслуживанию аудиоаппаратуры, музыкантов, вокалистов и т.д..

Спрос на изысканность и уникальность порождает и особые гастрономические заведения семейного типа или заведения с мономеню. Эти заведения не обслуживают много посетителей, и нередко имеют не более пяти, а то и меньше столиков. Туда попадают только по записи. Эти заведения не работают длительное время, и обслуживают посетителей только в обеденное время, а меню состоит из одного или пары блюд, на выбор повара - хозяина заведения. Он диктует свои условия, как, например, во всемирно известной севичерии перуанца китайского происхождения Хавьера Вонга. На его заведении нет вывески, так как он не нуждается в ней, нет очередей, как в некоторых заведениях, все максимально по-домашнему, и гости могут всегда пообщаться с поваром, который расскажет и даже покажет все секреты своего мастерства. Попасть сюда можно только по предварительной записи.

Но заведения, подобные севичерии Хавьера Вонга уже давно не являются чем-то уникальным, да и не считаются изобретением перуанцев. Это уже мировая тенденция, нацеленная на развитие персонального бренда.

Все, происходящее в Перу, очень хорошо попадает под определение схожего процесса складывания алиментарного ландшаффта в мексиканском Юкатане, названного мексиканским антропологом Стеффаном Игорем Айора-Диасом «натурализацией вкуса» (AyoraDiaz, pp. 114-152).

Вне всякого сомнения, этот процесс в Перу, как и в других латиноамериканских странах, во многом был сопряжен с процессами формирования национальной идентичности. Вместе с тем, следует учитывать, что это процесс проходил в период активного влияния на национальные культуры глобалистских тенденций. Однако, доминирование американской массовой культуры или культуры европейских стран в этом процессе не только не сказалось отрицательно на национальной кухне Перу, но даже нередко стимулировало продвижение национальных брендов. Так местный рынок быстро нашел свой противовес всемирно известной кока-коле, создав инка-колу, которая ни в коей мере не является репликой кока-колы, а выступает в качестве своего национального бренда, получившего определенную популярность и в других странах Латинской Америки ${ }^{1}$.

1 Курьезность этой ситуации заключается еще и в том, что перуанцы в большей степени могли бы претендовать на название «кока-кола», учитывая ту роль, которую играют листья коки в традиционной культуре индейцев Центральных Анд. 
Кроме инки-коль особую роль в кулинарном ландшафте играет и такой неповторимый напиток как чича морада, который изготавливают из определенного сорта кукурузы и различных фруктов. К слову сказать чичерии, т.е. заведения, в которых подают подобный напиток, также является достаточно распространённым явлением в Перу. Даже типичное итальянское ризотто превращается в Перу в региональное кинотто (Quinotto), в котором особую роль уже начинает играть вместо риса местное киноа, а в качестве мясной добавки там могут быть мясо креветок, моллюски или курица.

Практически большинство блюд Старого Света оказались переосмыслены и переделаны под местные продукты и местные вкусы. Это стремление вписать чужие блюда в региональные традиции коснулись всего алиментарного своеобразия, привнесенного в Перу извне. Все натурализовалось и приспособилось под местные нужды. Но именно в этом, как оказалось, и сказывалась притягательная сила местного ландшафта, которая сплачивала перуанцев и вновь прибывших.

Очень важно, что перуанское правительство очень хорошо осознало как важность этого процесса, так и его перспективность, особенно касательно аспекта развития национальной культуры. 26 октября 2007 года правительство Перу через Национальный институт культуры (Instituto Nacional de Cultura) присвоило национальной кухне статус национального культурного наследия (Matta R., 2011, p. 196).

Процессы, происходившие в алиментарном ландшафте Перу, и особенно старания перуанских поваров и интеллектуалов начали приносить ощутимые результаты: перуанская кухня получила высшие оценки у кулинарных экспертов и гурманов всего мира (Fraser; Mclaughlin; Miroff). Особенно активно это признание началось во втором десятилетии XXI в.. 23 марта 2011 г. по случаю празднования Панамериканского года культуры Организация американских государств присвоила кухне Перу статус «Культурного наследия американского континента для всего мира». К 2019 г. перуанская алиментарная традиция уже 8-й раз получает статус «лучшего кулинарного направления мира» по версии ведущих туристических агентств (World Travel Awards, etc.).

Но важно и другое. В этот период появляется уже новая кулинарная традиция, выражающая совершенно новаторские идеи, которые невозможно было предугадать какие-то лет 10 до этого. За эти годы старые мастера новоандской традиции подготовили новых мастеров, которые пошли еще дальше в развитии кулинарных 
традиций своей страны. Вне всякого сомнения, появились шеф-повара, которые вознесли перуанскую кухню на новый уровень. Среди подобных персонажей в первую очередь хотелось бы назвать такого ресторатора как Вирхилио Мартинес (Virgilio Martínez), открывшего в 2008 г. в Лиме свой первый ресторан Central. Следует заметить, что B. Мартинес не был новичком в ресторанном бизнесе, так как длительное время стажировался в престижных ресторанах мира, таких как Le Cordon Bleu в Оттаве и Лондоне, работал в знаменитых ресторанах, таких как Lutèce $e^{1}$ в Нью Йорке, и Can Fabes ${ }^{2}$ в Барселоне. Он также руководил ресторанами перуанской кухни Astrid \& Gastón ${ }^{3}$ в Колумбии и Испании.

Мартинес активно сотрудничал с Акурио. Последний даже привлекал его к особому рекламному проекту 2011 г. программы Marca $\mathrm{Peru}^{4}$, направленному на пропаганду перуанской культуры за рубежом. В ходе этого проекте Гастон Акурио высаживал культурный десант в маленьком американском городке Перу в шт. Небраска в США. В. Мартинес, уже упомянутый перуанский щеф-повар Х. Вонга, и некоторые другие перуанские кулинары угощали американцев своей продукцией. Г. Акурио выступал в качестве водителя автобуса (Matta \& García, 2019).

Деятельность В. Мартинеса - это кухня совершенно нового уровня. В своем ресторане Central он предложил новое видение перуанской гастрономической традиции. Его деятельность вышла за уровень только лишь кулинарного искусства. Теперь это и кулинария, и образовательные проекты, и особая энвайронменталистская философия, и многое другое. Свою концепцию нового ресторана В. Мартинес и его жена Пиа Леон (Pia León), а также сестра Вирхилиа Малена Мартинес построили на презентации природного своеобразия Перу, определяемого через термины вертикальной экологии. Меню их ресторана выстроено таким образом, чтобы оно отражало региональную специфику природного ландшафта, начинающегося от 25 м. над уровнем моря и до 4700 м.. В нем 19 остановок или блюд, каждое из которых приготовлено из продуктов особой зоны.

1 Ресторан французской кухни класса люкс. Он считался одним из 10 самых шикарных ресторанов в США.

2 Ресторан находился в местечке Сан-Селони, недалеко от Барселоны. Ресторан имел три звезды Мишлен $(1988,1990,1994)$.

3 Astrid \& Gastón - франшиза, принадлежащая Гастону Акурио и его жене Астрид. Рестораны Astrid \& Gastón были открыты по всему миру.

4 Перуанская рекламная компания и бренд, направленный на пропаганду перуанской продукции в других странах. Марка Перу объединила огромное количество национальных фирм (Perú Nebraska, 2011). В 2012 г. Марка Перу провела подобную компанию в итальянском городке Лорето, недалеко от Венеции. Выбор этого города был продиктован тем, что в Перу имеется одноименный департамент, расположенный в Селве. 


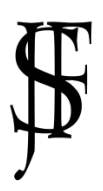

Журнал Фронтирных Исследований. 2021. No 3 | ISSN: 2500-0225

Фронтир в мировом контексте | Doi: https://doi.org/10.46539/jfs.v6i3.321

Начиная с Косты или побережья обед как бы охватывает все имеющиеся зоны (Сьерру и Сельву). Гость во время обеда знакомится со всем разнообразием природного мира этой страны.

Естественно, что кулинарная деятельность Мартинеса не зацикливается только на ресторанном бизнесе. Вместе с сестрой они создали важную структуру Mater Iniciativa, которая, по сути дела превратилась в научно-исследовательский институт, направленный на изучение биоразнообразия Перу (Mater Iniciativa; Lazar). Группа активно сотрудничает с различными крестьянскими общинами, кооперативами, производящими пищевые продукты в различных уголках Перу. Кроме этого сотрудники Mater Iniciativa создают своеобразный компендиум производимых продуктов в стране, фиксируют природное своеобразие, записывают различные кулинарные рецепты, делают фото и видеосъемку и т.д..

В. Мартинес привнес и новые формы обслуживания клиентов. Это касается посуды, столовых принадлежностей. Как правило, это уже не стандартные тарелки или ложки и вилки. В значительной степени это некая имитация традиционных форм принятия пищи. Здесь уже и каменные или глиняные сосуды, каменные палочки, заменяющие традиционные ложки и вилки. Все это, по мнению ресторатора, помогает лучше понять традиции принятия той или иной пищи, окунуться в неповторимую атмосферу культуры страны - от ее побережья до высокогорья и огромных пространств сельвы.

В ряде случаев Мартинесы предлагают есть пищу руками, так как это, согласно их видению ситуации, способствует пониманию пищи, которую едят посетители.

Все это создает неповторимую атмосферу обеда в ресторанах Мартинеса. Не удивтельно, что на сегодняшний день ресторан Central входит в десятку лучших ресторанов мира, занимая шестую позицию (Central, Lima, Peru, 2020). Правда, это не успех, а некоторая уступка лидирующего места, так как в 2015 он был на 4-ом месте. Кроме этого, Central считается лучшим рестораном в Латинской Америке. В настоящий момент В. Мартинес и его жена открыли еще несколько ресторанов в Перу, а также два ресторана в Лондоне (Lima London, 2012; Lima Floral, 2014) и в 2017 г. в Дубаи. В 2014 г. Лима Лондон получила звезду Мишлен. Это была первая звезда, присвоенная перуанскому ресторану в Британии.

Сама Пиа Леон теперь отдельно руководит и рестораном Kjolle (Койе), открывшимся в Лиме в 2018 г.. Кстати, именно в этом году ей был присвоен статус лучшего шеф-повара женщины в Латинской Америке. Сам ресторан в 2019 г. занял 21 место в списке лучших ресто- 
ранов Латинской Америке. В этом же году уже в Испании она стала первой в номинации «лучшая восходящая звезда поварского искусства» на конкурсе 100 лучших поваров мира. Как и ресторан Central, Kjolle также отличает большая оригинальность в подаче блюд, формировании меню и т.д.. Точнее там нет меню в привычном смысле этого слова, так как выбор и подача блюд максимально концептуальна. На самом деле посетителю предлагают кулинарное путешествие, приобщение к «духу» или «атмосфере» места, из которого прибыл этот продукт. С этой же целью Пиа Леон отказалась от скатертей, так как, по ее мнению, посетители должны ощущать поверхность, также, и еду. И посуда теперь оказывается не просто контейнером (пусть и красивым), а прежде всего неким посланием из того же места: поэтому это теперь деревянные тарелки из Амазонки, скорлупа кокоса или плод какао. Не только вкус блюда или его консистенция, теперь все должно играть четкую роль кулинарного нарратива. Это повествование начинается уже с самого названия ресторана Kjolle - название высокогорного цветка ярко оранжевого цвета. Здесь нет уже Haute cuisine в привычном смысле, но есть некий поиск, возведенный в ранг кулинарного искусства и гастрономического образования. Посетители уходят из этого ресторана не только сытые, но и много узнавшие, прикоснувшиеся к культурному и природному своеобразию этой страны.

Пример В. Мартинеса вместе с Г. Акурио, Мома Адриансеном ${ }^{1}$ и другими убедительно показывают, что гастрономический уровень перуанских рестораторов достиг очень больших высот, и он может конкурировать с ведущими французскими, средиземноморскими и американскими ресторанными традициями.

\section{ЗАКЛЮЧЕНИЕ}

За последнее время Перу превратилось в особую кулинарную Мекку, куда приезжают туристы не только ради традиционных культовых мест (Куско, Мачу-Пикчу, оз. Титикака, р. Амазонка и т.д.), но и ради посещения ведущих ресторанов с мировым именем.

Путь, который прошла перуанская алиментарная традиция от крестьянской кухни до изысканных блюд перуанской и мировой элиты, заслуживает всяческого внимания и ставит перед исследователями ряд важнейших гносеологических задач по пониманию процессов формирования алиментарного ландшафта.

1 Moma Adrianzén - новая восходящая звезда перуанской кухни. М. Адриансен на сегодняшний день владеет двумя ресторанами в Лиме (Jeronimo и Chinga Tu Taco) и одним в Сантьяго де Чили (Jeronimo). 


\section{Список литературы}

A Future Sown Thousands of Year Ago. (2013). (Food and Agriculture Organization of the United Nations) Retrieved 08 20, 2020, from Quinoa 2013 International Year: http:// www.fao.org/quinoa-2013/mobile/en/

Appadurai, A. (1981). Gastro-politics in Hindu South Asia. American Ethnologist, 8(3), 494511.

Ayora-Diaz, S. I. (2012). Foodscapes, Foodfields, and Identities in the Yucatan. New York: Berghahn Books.

Bauer, A. J. (2001). Goods, Power, History: Latin America's Material Culture. Cambridge, New York: Cambridge University Press.

Benavides de Rivero, G. (2003). Alimentación y gastronomía. II Coloquio Internacional de Gastronomía, Patrimonio y Turismo. Lima: Universidad de San Martín de Porres.

Benites, O. V. (2012). Gastronomía e identidad nacional. Trujillo: Edición del autor.

Benson, E. P. (2012). The Worlds of the Moche on the North Coast of Peru. Austin: University of Texas Press.

Cartay, R. (2016). La mesa amazónica peruana. Ingredientes, corpus y símbolos. Lima: Universidad de San Martin de Porres.

Central, Lima, Peru. (2020, n.d. n.d.). Retrieved 10 05, 2020, from The world's 50 Best Restaurants: https://www.theworlds50best.com/the-list/1-10/Central.html

Cieza de Leon, P. (2005). La Cronica del Peru. Caracas: Biblioteca de Ayacucho.

Clausen de Molina, G. H. (2018). La cocina del Perú. Lima: Planeta.

Drinot, P. (2005). Food, Race and Working-Class Identity: Restaurantes Populares and Populism in 1930s Peru. The Americas, 62(2), 245-270.

Drinot, P., \& Contreras, C. (2014). The Great Depression in Peru. B P. Drinot , \& A. Knight (Ред.), The Great Depression in Latin America (стр. 102-128). Durham, London: Duke University Press.

Engel, F. (1970). Exploration of the Chilca Canyon, Peru. Current Anthropology, 11, 55-58.

Ferguson, P. P. (2004). Accounting for taste: the triumph of French cuisine. Chicago: The University of Chicago Press.

Fraser, L. (August 2006 г.). Next Stop Lima. Gourmet, 66(8), 99-116.

Goldstein, P. S. (2000). Communities without Borders: The vertical archipelago and diaspora communities in the southern Andes. In M. A. Canuto, \& J. Yaeger (Eds.), The Archaeology of Communities: the New World Perspective (pp. 182-209). New York: Routledge.

Guardia, S. B. (2016). Cocina Peruana: Historia, cultura y sabores. Lima: Universidad de San Martin de Porres.

Kraig, B., \& Sen, C. T. (2013). Street Food around the World: An Encyclopedia of Food and Culture. Oxford: ABC-Clio. 
Lamana, G. (2008). Domination without Dominance: Inca-Spanish Encounters in Early Colonial Peru. Durham, London: Duke University Press.

Lauer, M. (2018). Comer en los mercados peruanos. Lima: Universidad de San Martin de Porres.

Lazar, A. (2018, Jun 29). How Malena Martínez Is Changing the Future of Peruvian Cuisine. Retrieved 10 5, 2020, from Eater: https:/www.eater.com/2018/6/29/17509624/ malena-martinez-mater-iniciativa-central-restaurant-peru-virgilio-martinez-interview

León, E. (2013). 14,000 años de alimentación en el Perú. Lima: Universidad de San Martín de Porres.

Llosa, M. V. (22 MAR 2009 г.). El sueño del 'chef'. El Pais. Retrieved 09092020 from https:// elpais.com/diario/2009/03/22/opinion/1237676414_850215.html

Mangan, J. E. (2016). Transatlantic Obligations: Creating the Bonds of Family in Conquest-era Peru and Spain. Oxford, New York: Oxford University Press.

Mater Iniciativa. (2013, n.d. n.d.). Retrieved 09 11, 2020 from Mater Iniciativa: https:// materiniciativa.com/

Matta, R. (2011). Posibilidades y límites del desarrollo en el patrimonio inmaterial. El caso de. Apuntes, 24(2), 196-207.

Matta, R., \& García, M. (2019). The Gastro-Political Turn in Peru. Anthropology of food, 14, 110. Retrieved 12 20, 2019 from http://journals.openedition.org/aof/10 061

Mclaughlin, K. (2011, September 10). The Next Big Thing: Peruvian Food. The Wall Street Fournal. Retrieved 10 01, 2020, from https://www.wsj.com/articles/food-s-next-bigthing-peruvian-11591297 138?tesla=y

Miroff, N. (2014, July 23). Gastón Acurio, South America's super chef. The Washington Post. Retrieved 09 29, 2020, from https://www.washingtonpost.com/world/gaston-acuriosouth-americas-super-chef/2014/07/23/2f7f05bd-a50b-4142-a5c3-

b3206f216eac_story.html

Murra, J. V. (1975). El control vertical de un máximo de pisos ecológicos en la economía de las sociedades andinas. In J. V. Murra, Formaciones Económicas y Politicas del Mundo Andino (pp. 59-116). Lima: Instituto de Estudios Peruanos.

National Fisheries Sector Overview Peru. (5 092020 г.). Получено 2020, из Food and Agriculture Organization of the United Nations: http://www.fao.org/fishery/docs/DOCUMENT/fcp/en/FI_CP_PE.pdf

Ndi, G. S. (2018). Reimagining Blackness in a Hybridized and Racialized Space. In C. Iheka (Ed.), African Migration Narratives: Politics, Race, and Space (pp. 114-140). Rochester: University of Rochester Press.

Olivas Weston, R. (1996). Cultura, Identidad y Cocina en el Peru. Lima: Universidad de San Martín de Porres.

Olivas Weston, R. (1998). La cocina en el virreynato del Peru. Lima: Universidad de San Martín de Porres. 


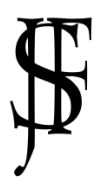

Журнал Фронтирных Исследований. 2021. No 3 | ISSN: 2500-0225

Фронтир в мировом контексте | Doi: https://doi.org/10.46539/jfs.v6i3.321

Olivas Weston, R. (1999). La cocina cotidiana y festiva de los limeños en el siglo XIX. Lima: Universidad de San Martín de Porres.

Olivas Weston, R. (2008). Cusco. El imperio de la cocina. Lima: Universidad de San Martin de Porres.

Olivas Weston, R. (2015). La cocina de los Incas. Costumbres gastronómicas y técnicas culinarias. Lima: Universidad de San Martin de Porres.

Orefici, G. (2019). Cultura alimentaria de los antiguos Nasca. Lima: Universidad de San Martín de Porres.

O'Toole, R. S. (2012). Bound Lives: Africans Indians and the Making of Race in Colonial Peru. Pittsburgh: University of Pittsburgh Press.

Perú Nebraska. (2011, n.d. n.d.). Retrieved 09 20, 2020 from Marca Perú: Un símbolo que une a todo el país: https://peru.info/es-pe/marca-peru/detalle-campanas/1/peru-nebraska

Peruvian Camu Camu fruit conquers fapan. (2007, 02 12). Retrieved 09 12, 2020, from Traveling and Living in Peru: https://www.livinginperu.com/business-263-agricultureperuvian-camu-camu-fruit-conquers-japan/

Prescott, W. H. (2013). History of the Conquest of Peru. New York: Dover Publication.

Radiguet, M. (1859). Souvenirs de l'Amérique Espagnole : Chili, Pérou, Brésil. Paris: Michel Levy Freres.

Stanish, C. (2003). Ancient Titicaca: The Evolution of Complex Society in Southern Peru and Northern Bolivia. Berkeley; London: University of California Press.

Steward, J. H. (1946). Handbook of South American Indians (V. 2). Washington, U.S. Govt. Print Off.

Tristán, O. M., \& Serida-Nishimura, J. (2014). A Chef's Dream. In L. Liberman, S. Garcilazo, \& E. Stal (Eds.), Multinationals in Latin America: Case Studies (pp. 83-98). New York: Palgrave Macmillan.

Villavicencio, M. (2017). Mujer, poder y alimentación en el Antiguo Perú. Lima: Universidad de San Martin de Porres.

Villavicencio, M. F. (2007). Seminario Historia de la Cocina Peruana. Lima: Universidad de San Martín de Porres.

Якушенков, С. Н. (1988). Вертикальная экология и семантика пространства в представлении аймара. В Экология американских индейцев и эскимосов (сс. 276-287). М.: Наука.

Якушенков, С. Н., \& Палаткин, В. В. (2020). Мы наш и новый мир накормим: несколько кейсов алиментарных традиций фронтирных регионов. Часть 1. Журнал фронтирных исследований, 5(4), 237-285. doi: 10.46539/jfs.v5i4.241 


\section{References}

A Future Sown Thousands of Year Ago. (2013). (Food and Agriculture Organization of the United Nations) Retrieved 08 20, 2020, from Quinoa 2013 International Year: http:// www.fao.org/quinoa-2013/mobile/en/

Appadurai, A. (1981). Gastro-politics in Hindu South Asia. American Ethnologist, 8(3), 494511.

Ayora-Diaz, S. I. (2012). Foodscapes, Foodfields, and Identities in the Yucatan. New York: Berghahn Books.

Bauer, A. J. (2001). Goods, Power, History: Latin America's Material Culture. Cambridge, New York: Cambridge University Press.

Benavides de Rivero, G. (2003). Alimentación y gastronomía. II Coloquio Internacional de Gastronomía, Patrimonio y Turismo. Lima: Universidad de San Martín de Porres.

Benites, O. V. (2012). Gastronomía e identidad nacional. Trujillo: Edición del autor.

Benson, E. P. (2012). The Worlds of the Moche on the North Coast of Peru. Austin: University of Texas Press.

Cartay, R. (2016). La mesa amazónica peruana. Ingredientes, corpus y símbolos. Lima: Universidad de San Martin de Porres.

Central, Lima, Peru. (2020, n.d. n.d.). Retrieved 10 05, 2020, from The world's 50 Best Restaurants: https://www.theworlds50best.com/the-list/1-10/Central.html

Clausen de Molina, G. H. (2018). La cocina del Perú. Lima: Planeta.

Drinot, P. (2005). Food, Race and Working-Class Identity: Restaurantes Populares and Populism in 1930s Peru. The Americas, 62(2), 245-270.

Drinot, P., \& Contreras, C. (2014). The Great Depression in Peru. B P. Drinot , \& A. Knight (Ред.), The Great Depression in Latin America (стр. 102-128). Durham, London: Duke University Press.

Engel, F. (1970). Exploration of the Chilca Canyon, Peru. Current Anthropology, 11, 55-58.

Ferguson, P. P. (2004). Accounting for taste: the triumph of French cuisine. Chicago: The University of Chicago Press.

Fraser, L. (August 2006 г.). Next Stop Lima. Gourmet, 66(8), 99-116.

Goldstein, P. S. (2000). Communities without Borders: The vertical archipelago and diaspora communities in the southern Andes. In M. A. Canuto, \& J. Yaeger (Eds.), The Archaeology of Communities: the New World Perspective (pp. 182-209). New York: Routledge.

Guardia, S. B. (2016). Cocina Peruana: Historia, cultura y sabores. Lima: Universidad de San Martin de Porres.

Kraig, B., \& Sen, C. T. (2013). Street Food around the World: An Encyclopedia of Food and Culture. Oxford: ABC-Clio.

Lamana, G. (2008). Domination without Dominance: Inca-Spanish Encounters in Early Colonial Peru. Durham, London: Duke University Press. 


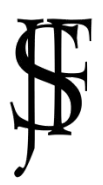

Журнал Фронтирных Исследований. 2021. No 3 | ISSN: 2500-0225

Фронтир в мировом контексте | Doi: https://doi.org/10.46539/jfs.v6i3.321

Lauer, M. (2018). Comer en los mercados peruanos. Lima: Universidad de San Martin de Porres.

Lazar, A. (2018, Jun 29). How Malena Martinez Is Changing the Future of Peruvian Cuisine. Retrieved 10 5, 2020, from Eater: https:/www.eater.com/2018/6/29/17509624/ malena-martinez-mater-iniciativa-central-restaurant-peru-virgilio-martinez-interview

León, E. (2013). 14,000 años de alimentación en el Perú. Lima: Universidad de San Martín de Porres.

Llosa, M. V. (22 MAR 2009 г.). El sueño del 'chef'. El Pais. Retrieved 09092020 from https:// elpais.com/diario/2009/03/22/opinion/1 $237676414 \_850215 . h t m l$

Mangan, J. E. (2016). Transatlantic Obligations: Creating the Bonds of Family in Conquest-era Peru and Spain. Oxford, New York: Oxford University Press.

Mater Iniciativa. (n.d. de 2013). Recuperado el 11 de 09 de 2020, de Mater Iniciativa: https:// materiniciativa.com/

Matta, R. (2011). Posibilidades y límites del desarrollo en el patrimonio inmaterial. El caso de. Apuntes, 24(2), 196-207.

Matta, R., \& García, M. (2019). The Gastro-Political Turn in Peru. Anthropology of food, 14, 110. Recuperado el 20 de 12 de 2019, de http://journals.openedition.org/aof/10 061

Mclaughlin, K. (2011, September 10). The Next Big Thing: Peruvian Food. The Wall Street fournal. Retrieved 10 01, 2020, from https://www.wsj.com/articles/food-s-next-bigthing-peruvian-11591297 138?tesla=y

Miroff, N. (2014, July 23). Gastón Acurio, South America's super chef. The Washington Post. Retrieved 09 29, 2020, from https://www.washingtonpost.com/world/gaston-acuriosouth-americas-super-chef/2014/07/23/2f7f05bd-a50b-4142-a5c3b3206f216eac_story.html

Murra, J. V. (1975). El control vertical de un máximo de pisos ecológicos en la economía de las sociedades andinas. En J. V. Murra, Formaciones Económicas y Politicas del Mundo Andino (págs. 59-116). Lima: Instituto de Estudios Peruanos.

National Fisheries Sector Overview Peru. (5 092020 г.). Retrieved 2020, from Food and Agriculture Organization of the United Nations: http://www.fao.org/fishery/docs/DOCUMENT/fcp/en/FI_CP_PE.pdf

Ndi, G. S. (2018). Reimagining Blackness in a Hybridized and Racialized Space. In C. Iheka (Ed.), African Migration Narratives: Politics, Race, and Space (pp. 114-140). Rochester: University of Rochester Press.

Olivas Weston, R. (1996). Cultura, Identidad y Cocina en el Peru. Lima: Universidad de San Martín de Porres.

Olivas Weston, R. (1998). La cocina en el virreynato del Peru. Lima: Universidad de San Martín de Porres.

Olivas Weston, R. (1999). La cocina cotidiana y festiva de los limeños en el siglo XIX. Lima: Universidad de San Martín de Porres. 
Olivas Weston, R. (2008). Cusco. El imperio de la cocina. Lima: Universidad de San Martin de Porres.

Olivas Weston, R. (2015). La cocina de los Incas. Costumbres gastronómicas y técnicas culinarias. Lima: Universidad de San Martin de Porres.

Orefici, G. (2019). Cultura alimentaria de los antiguos Nasca. Lima: Universidad de San Martín de Porres.

O'Toole, R. S. (2012). Bound Lives: Africans Indians and the Making of Race in Colonial Peru. Pittsburgh: University of Pittsburgh Press.

Perú Nebraska. (n.d. de n.d. de 2011). Recuperado el 20 de 09 de 2020, de Marca Perú: Un símbolo que une a todo el país: https://peru.info/es-pe/marca-peru/detallecampanas/1/peru-nebraska

Peruvian Camu Camu fruit conquers fapan. (2007, 02 12). Retrieved 09 12, 2020, from Traveling and Living in Peru: https://www.livinginperu.com/business-263-agricultureperuvian-camu-camu-fruit-conquers-japan/

Prescott, W. H. (2013). History of the Conquest of Peru. New York: Dover Publication.

Radiguet, M. (1859). Souvenirs de l'Amérique Espagnole : Chili, Pérou, Brésil. Paris: Michel Levy Freres.

Stanish, C. (2003). Ancient Titicaca: The Evolution of Complex Society in Southern Peru and Northern Bolivia. Berkeley; London: University of California Press.

Steward, J. H. (1946). Handbook of South American Indians (V. 2). Washington, U.S. Govt. Print Off.

Tristán, O. M., \& Serida-Nishimura, J. (2014). A Chef’s Dream. In L. Liberman, S. Garcilazo, \& E. Stal (Eds.), Multinationals in Latin America: Case Studies (pp. 83-98). New York: Palgrave Macmillan.

Villavicencio, M. (2017). Mujer, poder y alimentación en el Antiguo Perú. Lima: Universidad de San Martin de Porres.

Villavicencio, M. F. (2007). Seminario Historia de la Cocina Peruana. Lima: Universidad de San Martín de Porres.

Yakushenkov, S. N. (1988). Vertical'naya ekologia y semantika prostranstva v predstavlenii aymara. In Ekologia amerikanskih indeytsev y eskimosov (pp. 276-287). Moscow: Nauka. (In Russian).

Yakushenkov, S. N., \& Palatkin, V. V. (2020). We will feed our and a new world: several cases of food ways of frontier regions. Part I. Journal of Frontier Studies, 5(4), 237-285. doi: 10.46539/jfs.v5i4.241 (In Russian). 